\title{
ANALISIS KETERWAKILAN PEREMPUAN DALAM PEMILIHAN LEGISLATIF
}

\author{
Efendi dan Atika Rahayu \\ Sekolah Tinggi Ilmu Administrasi Nusantara Sakti Sungai Penuh \\ Email: \\ efendidahlan1977@gmail.com \\ atika436@gmail.com
}

\begin{abstract}
The representation of women in the legislative field, especially in the election of legislative members in 2019 is quite large and of course will provide balance and color the formulation of laws and regulations, budgeting and supervision with a gender perspective in Sungai Penuh City, so that the presence of women in the political arena is not only a formality. The formulation of the research problem, namely, how is the representation of women in the legislative elections (Case Study at the Sungai Penuh City DPRD 2019)? The research objective is to determine the representation of women in the legislative elections (Case Study at the River City DPRD 2019). This research uses a qualitative approach where data is obtained through field interviews with 5 informants referring to 4 research indicators, namely 1. Socialization 2. Recruitment. 3. Cadreization 4. Communication. The data obtained in the field were analyzed based on the classification of the informants' answers which were described in the results and discussion of the research which was then carried out by the interpreter of the researcher.It is known that the representation of women in the legislative elections (Case Study at the Sungai Penuh City DPRD 2019) from the four research indicators, none of them can represent the voice of women in the Sungai Penuh City DPRD. The lack of maximum presence of women in legislative elections so that they do not get vote support.
\end{abstract}

\section{Keywords: Women's Representation, Legislative Election}

\begin{abstract}
ABSTRAK
Keterwakilan perempuan di bidang legislatif, khususnya didalam pemilihan anggota legislatif pada tahun 2019 cukup besar dan tentunya akan memberikan keseimbangan dan mewarnai perumusan peraturan perundang-undangan, penganggaran dan pengawasan yang berspektif gender di Kota Sungai Penuh, sehingga kehadiran perempuan dalam arena politik tidak hanya sebatas formalitas belaka. Rumusan masalah penelitian yaitu, bagaimanakah keterwakilan perempuan dalam pemilihan legislatif (Studi Kasus di DPRD Kota Sungai Penuh Tahun 2019)? Tujuan penelitian yaitu, Untuk mengetahui keterwakilan perempuan dalam pemilihan legislatif (Studi Kasus di DPRD Kota Sungai Penuh Tahun 2019). Penelitiaan ini menggunakan pendekatan kualitatif dimana data diperoleh melalui wawancara dilapangan kepada 5 orang informan yang mengacu kepada 4 indikator penelitian yaitu 1. Sosialisasi 2. Rekruitmen. 3. Kaderisasi 4. Komunikasi. Data yang diperoleh dilapangan dianalisis berdasarkan pengklasifikasian jawaban informan yang diuraikan dalam hasil dan pembahasan penelitian yang kemudian dilakukan interpretatif peneliti. Diketahui bahwa keterwakilan perempuan dalam pemilihan legislatif (Studi Kasus di DPRD Kota Sungai Penuh Tahun 2019) dari empat indikator penelitian tidak satupun dapat mewakili suara perempuan di DPRD Kota Sungai Penuh. Kurang maksimalnya existensi perempuan dalam pemilihan legislatif sehingga tidak mendapatkan dukungan suara.
\end{abstract}

\section{Kata Kunci : Keterwakilan Perempuan, Pemilihan Legislatif}




\section{PENDAHULUAN}

Kehadiran perempuan diranah legislatif yang dibuktikan dengan keterwakilan perempuan di parlemen menjadi syarat mutlak bagi terciptanya kultur pengambilan kebijakan publik yang ramah dan sensitif pada kepentingan perempuan. Tanpa keterwakilan perempuan diparlemen dalam jumlah yang memadai, kecenderungan untuk menempatkan kepentingan laki-laki sebagai pusat dari pengambilan kebijakan akan sulit dibendung. Minimnya keterwakilan perempuan di dalam lembaga-lembaga pengambilan keputusan di Indonesia menjadi persoalan ketika transisi menuju demokrasi menuntut kesetaraan dan keadilan perempuan. Kondisi sosiokultur bangsa yang pekat dengan budaya patriarki menjadi salah satu faktor penghalang untuk aktualisasi perempuan sebagai pengambil kebijakan pembangunan bangsa ini

Dalam aspek politik, masih banyak orang menomorduakan perempuan dalam keterlibatannya di dunia politik. Perempuan masuk di dunia legislatif atau masuk dalam pemilihan umum hanya untuk memenuhi syarat pembentukan legislatif. Perempuan seringkali menjadi subordinasi dari laki-laki dalam berbagai hal, khususnya penentuan dan pengambilan kebijakan. Dilembaga legislatif terjadi kesenjangan yang cukup lebar dalam setiap keterwakilan perempuan.

Tampaknya, harapan aktivis perempuan untuk mewujudkan persamaan di bidang politik masih jauh dari kenyataan. Hal ini setidaknya dapat dilihat dari kuantitas maupun kualitas perempuan di parlemen nasional dan daerah belum signifikan. Artinya, jumlah perempuan yang duduk dilembaga legislatif masih jauh dari yang dicita-citakan (di bawah kuota 30 persen). Disamping itu, perempuan yang menduduki posisi strategis dalam kepengurusan legislatif juga sangat sedikit. Hal ini berdampak pada proses pencalegan dan keterwakilan perempuan di parlemen.

Dengan demikian, paling tidak ada dua persoalan perempuan dalam legislatif yaitu masalah partisipasi perempuan yang masih rendah. di ruang legislatif dan masalah belum adanya platform partai yang secara konkret membela kepentingan perempuan.

Partisipasi perempuan Indonesia dalam lembaga legislatif, bukanlah merupakan hal yang baru lagi. Perempuan telah turut serta secara aktif dalam pergerakan kebangsaan bahkan sebelum datangnya masa kolonialisme. Partisipasi perempuan dalam legislatif merupakan kegiatan seseorang atau sekelompok orang untuk ikut secara aktif dalam kehidupan politik, yaitu dengan jalan memilih pemimpin negara dan langsung atau tidak langsung mempengaruhi kebijakan publik. Kegiatan ini mencakup tindakan seperti memberikan suara dalam pemilihan umum, mengahadiri rapat umum, menjadi anggota suatu partai atau kelompok kepentingan, mengadakan hubungan dengan pejabat pemerintah atau anggota perlemen, dan sebagainya.

Salah satu wujud nyata dari tumbuhnya kesadaran kekuatan politik perempuan ditandai dengan keterlibatan secara aktif perempuan dalam proses-proses legislatif. Keterwakilan perempuan dalam legislatif secara nyata tidak saja didasarkan pada keikutsertaannya dalam pengambilan keputusan, tetapi juga kontribusinya untuk memperjuangkan hak-hak kaum perempuan.

Undang-undang Nomor 7 Tahun 2017 pada pasal 173 ayat 2 huruf e berbunyi, menyatakan paling sedikit $30 \%$ keterwakilan perempuan pada kepengurusan partai politik. Selanjutnya lebih ditegaskan lagi keterwakilan perempuan yaitu pada pasal 298 ayat 3 yang berbunyi "KPU kabupaten/kota melakukan verifikasi terhadap kelayakan dan kebenaran dalam persyaratan. Peraturan KPU Nomor 10 tahun 2018 tentang sosialisasi, Pendidikan pemilih dan partisipasi masyarakat dalam pemilu mengartikan, Partisipasi Masyarakat merupakan keterlibatan perorangan dan/atau kelompok dalam Penyelenggaraan Pemilu.

Keterwakilan perempuan mengandung arti bahwa walaupun saat ini hak-hak legislatif perempuan sudah banyak diakui, namun ternyata hak-hak legislatif tersebut belum menjamin 
adanya pemerintahan demokratis, sebab asas partisipasi, representasi dan akuntabilitas tidak diberi makna sesungguhnya. Ini artinya, adanya keterwakilan perempuan didalamnya dan berbagai kebijakan yang diambil yang bermuara pada keadilan gender, tidak serta merta dapat terwujud kendatipun hak-hak politik perempuan sudah diakui. Padahal sesungguhnya keterwakilan perempuan pada lembaga perwakilan sangatlah penting. Karena hanya perempuan yang mampu, memahami, merasakan, dan berempati terhadap masalah dan aspirasi perempuan. Partai politik memiliki peranan yang sangat penting untuk menunjang kualitas dan kuantitas perempuan untuk masuk ke dalam lembaga legislatif. Partai politik merupakan wadah untuk menciptakan kesetaraan dan keadilan gender.

Kualitas dan kuantitas adalah dua hal penting yang harus diperhatikan dalam rangka mendorong partisipasi perempuan di dalam politik. Partai politik harus bisa terbebas dari penilaian atau pandangan terhadap seseorang hanya berdasarkan persepsi yang menganggap bahwa politik merupakan ranah maskulin yang tidak cocok untuk perempuan. Penting untuk meningkatkan keterlibatan perempuan dalam legislatif dengan meningkatkan kesadaran akan peluang yang ada, membangun kepercayaan diri dan keterampilan yang dimiliki oleh perempuan.

Hal ini diperlukan sehingga kehadiran perempuan dalam arena politik tidak hanya sebatas formalitas belaka. Tidak hanya itu, sistem juga turut mempengaruhi keberhasilan dalam meningkatkan partisipasi perempuan dalam politik. Sistem yang dimaksud di sini mencakup sistem perekrutan kader, pemberdayaan kader, serta sistem pemilu yang diterapkan.

Sistem pemilu yang berlaku masih menjadikan perempuan sebatas syarat partai politik untuk dapat mengikuti pemilu. Hal ini justru semakin mengukuhkan bahwa perempuan hanya menjadi objek semata. Tujuan dari kebijakan afirmasi tentunya tidak akan tercapai ketika sistem yang mengatur tidak mendukung perempuan untuk beraktualisasi dan berkembang. Jaminan persamaan kedudukan laki-laki dan perempuan khususnya di bidang pemerintahan dan hukum telah ada sejak diundangkannya Undang-Undang Dasar 1945, 17 Agustus 1945, Pasal 27 ayat (1), menyebutkan bahwa: "Segala warga negara bersamaan kedudukannya di dalam hukum dan pemerintahan dan wajib menjunjung hukum dan pemerintahan itu dengan tidak ada kecualinya". Negara yang menganut sistem demokrasi perwakilan, pertanggungjawaban pemerintah kepada rakyat disampaikan melalui lembaga perwakilan rakyat.

Berbicara tentang hak politik perempuan, tidak ada satu aturan pun yang tidak mengakui hak memilih dan dipilih perempuan. Pada kenyataannya, perempuan lebih banyak menggunakan salah satu haknya, yaitu sebagai pemilih semata. Dalam hal ini partisipasi politik perempuan rendah. Sementara haknya untuk dipilih kurang diaplikasikan, sebab hukum tidak memberi dorongan untuk hal itu.

Nilai-nilai yang timpang dalam masyarakat tentang hubungan gender telah terinternalisasi ke dalam diri perempuan dan diterima sebagai kebenaran oleh masyarakat luas. Tanpa bantuan hukum akan sulit mendorong perempuan untuk menggunakan haknya itu. Dengan kata lain, tidak adanya dukungan struktural akan membuat perempuan sulit melawan arus kultural yang melingkupi mereka sedikit mengingat bahwa prinsip dasar kehidupan kenegaraan yang demokratis adalah setiap warga negara berhak ikut aktif dalam proses politik.

Disampaikan salah satu syarat dasar untuk terselenggaranya pemerintahan yang demokratis di bawah Rule of Law adalah perlindungan konstitusional, dalam arti bahwa konstitusi selain dari menjamin hak-hak individu, harus menentukan juga cara prosedural untuk memperoleh perlindungan atas hak-hak yang dijamin. Keadilan menuntut pentingnya distribusi yang sifatnya adil atas semua kesempatan, peranan, kedudukan, serta manfaatmanfaat atau nilai-nilai sosial asasi yang terdapat di dalam masyarakat. 
Terobosan atau kebijakan khusus perlu dipikirkan, untuk memungkinkan kaum perempuan berkesempatan meraih posisi-posisi dalam panggung kemasyarakatan dan politik. Undang-undang Nomor 7 Tahun 2017 Pada pasal 448 menyebutkan bahwa Pemilu diselenggarakan dengan partisipasi masyarakat. Dengan kebijakan ini diharapkan tingkat keterwakilan perempuan di parlemen meningkat. Pada tabel di bawah ini dapat dilihat partisipasi perempuan dalam pemilihan legislatif pada pemilu 2019.

Tabel 1.1

Gambaran Jumlah Partisipasi Perempuan Pada Pemilu Tahun 2019

\begin{tabular}{|c|c|c|c|c|c|c|}
\hline \multirow[t]{2}{*}{ NO } & \multirow[t]{2}{*}{ PARTAI } & \multicolumn{3}{|c|}{ DAPIL } & \multicolumn{2}{|c|}{ JUMLAH } \\
\hline & & 1 & 2 & 3 & LK & PR \\
\hline 1 & PKB & 6 & 5 & 2 & 8 & 5 \\
\hline 2 & GERINDRA & 10 & 8 & 6 & 15 & 9 \\
\hline 3 & PDI-P & 6 & 3 & 6 & 10 & 5 \\
\hline 4 & GOLKAR & 6 & 9 & - & 10 & 5 \\
\hline 5 & NASDEM & 7 & 7 & 5 & 12 & 7 \\
\hline 6 & PARTAI BERKARYA & 7 & 3 & 4 & 6 & 8 \\
\hline 7 & PKS & 10 & 8 & 6 & 16 & 8 \\
\hline 8 & PERINDO & 4 & 6 & - & 5 & 5 \\
\hline 9 & PPP & 10 & 7 & 6 & 16 & 7 \\
\hline 10 & PAN & 10 & 9 & 6 & 17 & 8 \\
\hline 11 & HANURA & 5 & 7 & 4 & 9 & 7 \\
\hline 12 & DEMOKRAT & 10 & 4 & 6 & 12 & 8 \\
\hline 13 & BULAN BINTANG & 4 & 2 & - & 2 & 4 \\
\hline 14 & PKPI & 3 & 2 & - & 3 & 2 \\
\hline & & 98 & 80 & 51 & 141 & 88 \\
\hline
\end{tabular}

Sumber : KPU Kota Sungai Penuh Tahun 2020

Dari tabel 1.1 diatas dapat dilihat bahwa keterwakilan perempuan dalam politik di Indonesia yang hanya mendapatkan 30\% menjadi wacana yang penting dalam upaya meningkatkan partisipasi politik perempuan. Begitu juga halnya dengan daerah Kota Sungai Penuh begitu besarnya harapan kaum perempuan untuk dapat berpartisipasi dalam pemilihan anggota legislatif tidak hanya dikarena karena adanya kuota yang harus dipenuhi oleh partai yang ikut dalam pemilihan legislatif tersebut tetapi karena adanya keinginan perempuan yang menginginkan kemajuan dalam bidang legislatif, maka penempatan posisi perempuan pada legislatif di Kota Sungai Penuh menjadi sangat penting. Hal ini merupakan bagian dari kehidupan berdemokrasi dan transparansi dalam penyelenggaraan di koat Sungai Penuh. Keterlibatan kaum perempuan di bidang legislatif, khususnya didalam pemilihan anggota legislatif pada tahun 2019 cukup besar dan tentunya akan memberikan keseimbangan dan mewarnai perumusan peraturan perundang-undangan, penganggaran dan pengawasan yang berspektif gender di Kota Sungai Penuh.

Disamping itu partisipasi perempuan dalam pemilihan legislatif pada tahun 2019 sangat penting artinya bagi perempuan lainnya yang jumlah perempuan pemilih cukup besar yang tentunya akan memberikan harapan agar harapan dan aspirasi mereka akan dapat tersalurkan melalui keikutsertaan perempuan dalam pemilihan legislatif.

Dari pengamatan awal dilapangan ditemukan fenomena sebagai berikut :

1. Kurangnya sosialisasi keterwakilan perempuan dalam politik seperti pemilihan anggota legislatif . 
2. Belum maksimalnya rekruitmen perempuan didalam pemilihan politik hanya sebagai pelengkap yang menduduki deretan urutan bagian akhir.

3. Belum maksimalnya kaderisasi perempuan dalam pemilihan umum pada seperti kurangnya setiap partai politik yang mencalonkan anggota perempuan dalam pemlihan umum.

4. Kurang komunikasi tentang keterlibatan perempuan dalam pemilihan legislatif karena untuk pemilihan umum hanya untuk melengkapi persayaratan keanggotaan.

Bedasarkan latar belakang diatas dapat diambil rumusan masalah yaitu:

1. Bagaimanakah Keterwakilan Perempuan Dalam Pemilihan Legislatif (Studi Kasus di DPRD Kota Sungai Penuh tahun 2019)?

2. Faktor-faktor apa saja yang mempengaruhi Keterwakilan Perempuan Dalam Pemilihan Legislatif (Studi Kasus di DPRD Kota Sungai Penuh tahun 2019)?

Sedangkan tujuan penelitian ini adalah untuk mengetahui Keterwakilan Perempuan Dalam Pemilihan Legislatif (Studi Kasus di DPRD Kota Sungai Penuh tahun 2019) dan untuk mengetahui faktor-faktor apa saja yang mempengaruhi Keterwakilan Perempuan Dalam Pemilihan Legislatif (Studi Kasus Di DPRD Kota Sungai Penuh tahun 2019).

\section{METODE PENELITIAN}

Dalam Penelitian ini penulis menggunakan pendekatan Kualitatif yaitu meneliti suatu objek penelitian dengan mengkaji secara keseluruhan dan mendalam bukan melihat hubungan dua variabel atau lebih. Dimana hasil penelitian akan diolah berdasarkan interpretatif peneliti dan diuraikan dalam bentuk deskriptif. Lexy J.Moleong (2009:21)

\section{Gambar 1.1}

Kerangka Pemikiran

\begin{tabular}{|ll|}
\hline \multicolumn{1}{|c|}{$\begin{array}{c}\text { Keterwakilan Perempuan di DPRD } \\
\text { Pemilu 2019 }\end{array}$} \\
\hline 1. & Sosialisasi \\
2. & Rekruitmen \\
3. & Kaderisasi \\
4. & Komunikasi \\
\hline
\end{tabular}

\section{Informan Penelitian Dan Teknik Penentuan Informan}

Teknik penentuan informan merupakan teknik pengambilan sampel untuk menentukan sampel yang akan digunakan dalam penelitian. Sugiono, (2007:91). Dalam penelitian Kualitatif teknik yang dipakai adalah proposif sampling yaitu bagaimana menentukan informan kunci atau situasi sosial tertentu yang sarat informasi sesuai dengan fokus penelitian. Bugin, (2003:53). Pemilihan informan kunci diperolah secara purposive sampling yaitu sampel yang diambil secara sengaja dan informan biasa dilakukan dengan cara purposive sampling yaitu sampel yang diambil berdasarakan ketentuan atau kriteria tertntu dari peneliti yaitu perempuan atau anggota dari partai politik yang ikut dalam pemilihan umum tahun 2019 di Kota Sungai Penuh.

Dalam menentukan informan yang akan dipakai dalam suatu penelitian, ada lima kriteria untuk pemilihan informan yaitu:

1. Subjek yang telah cukup lama dan intensif menyatu dengan kegiatan atau aktifitas yang menjadi informasi; 
2. Subjek yang masih terlibat secara penuh/aktif pada lingkungan atau kegiatan yang menjadi perhatian peneliti;

3. Subjek yang mempunyai cukup banyak waktu atau kesempatan untuk diwawancarai;

4. Subjek yang dalam memberikan informasi tidak cenderung diolah atau dipersiapkan terlebih dahulu;

5. Subjek sebelumnya tergolong masih "asing" dengan penelitian, sehingga peneliti merasa tertantang untuk belajar sebanyak mungkin dari subjek yang berfungsi sebagai "guru baru' bagi peneliti.

Mengacu pada pendapat ahli diatas dalam penelitian ini penulis mengambil informan dengan kriteria, yaitu: ketua, wakil DPRD dan perempuan-perempuan yang ikut dalam pemilihan umum tahun 2019 di Kota Sungai Penuh, dengan alasan lebih karena dalam penelitian ini membahas tentang keterwakilan perempuan di DPRD hasil pemilu 2019 di Kota Sungai Penuh. Informan penelitian dapat dilihat pada tabel 1.2 di bawah ini.

Tabel 1.2

Informan Penelitian

\begin{tabular}{|l|l|l|l|}
\hline NO & Nama & Jabatan & Partai \\
\hline 1 & Yoshadi & Anggota DPRD & PAN \\
\hline 2 & Lendra Wijaya & Anggota DPRD & Demokrat \\
\hline 3 & Weti Retmalia & Perempuan wakil legislatif Pemilu 2019 & Demokrat \\
\hline 4 & Mela Silvia & Perempuan wakil legislatif Pemilu 2019 & Nasdem \\
\hline 5 & Yola anggraini & Perempuan wakil legislatif Pemilu 2019 & Perindo \\
\hline Jumlah : 5 Orang Informan & \\
\hline
\end{tabular}

Sumber : DPRD Kota Sungai Penuh Tahun 2020

\section{Jadwal Penelitian}

Adapun jadwal dari penelitian bisa dilihat pada tabel di bawah ini :

Tabel 1.3

Jadwal Penelitian

\begin{tabular}{|c|c|c|c|c|c|c|c|c|c|c|c|c|c|c|c|c|c|c|}
\hline \multirow[t]{2}{*}{ No } & \multirow[t]{2}{*}{ Kegiatan } & \multicolumn{4}{|c|}{$\begin{array}{l}\text { Mei } \\
2020\end{array}$} & \multicolumn{4}{|c|}{$\begin{array}{l}\text { Juni } \\
2020\end{array}$} & \multicolumn{5}{|c|}{ Juli 2020} & \multicolumn{4}{|c|}{$\begin{array}{l}\text { Agus } \\
2020 \\
\end{array}$} \\
\hline & & 1 & 2 & 3 & 4 & 1 & 2 & 3 & 4 & 1 & 2 & 3 & & 5 & 1 & 2 & & 4 \\
\hline 1 & Pengajuan Judul & & & & & & & & & & & & & & & & & \\
\hline 2 & Acc Judul Proposal & & & & & & & & & & & & & & & & & \\
\hline 3 & Bimbingan Proposal & & & & & & & & & & & & & & & & & \\
\hline 4 & Seminar Proposal & & & & & & & & & & & & & & & & & \\
\hline 5 & Perbaikan Proposal & & & & & & & & & & & & & & & & & \\
\hline 6 & Pengambilan Data & & & & & & & & & & & & & & & & & \\
\hline 7 & Bimbingan Skripsi & & & & & & & & & & & & & & & & & \\
\hline 8 & Ujian Skripsi & & & & & & & & & & & & & & & & & \\
\hline
\end{tabular}




\title{
HASIL PENELITIAN DAN PEMBAHASAN
}

\author{
Analisis Keterwakilan Perempuan Dalam Pemilihan Legislatif (Studi Kasus Di DPRD Kota \\ Sungai Penuh Tahun 2019).
}

Dalam penelitian ini dilakukan pengambilan data dilapangan dengan menggunakan pedoman wawancara dengan 5 orang informan dengan lokasi penelitian di DPRD Kota Sungai Penuh dari tanggal 15 Juli sampai tanggal 29 Juli 2020 kemudian pembahasan data diuraikan berdasarkan urutan indikator dari setiap informan, setelah itu hasil penelitian dibuat dalam bentuk kesimpulan berdasarkan interpretatif dari peneliti pada setiap indikator penelitian.

\section{Defenisi Operasional variabel}

Menurut G.A. Almon (dalam Rahman 2007:29) indikator pnelitian yaitu:

\section{Sosialisasi}

Proses sosialisasi dipengaruhi oleh pengalaman sebelumnya yang diperoleh individu dalam kehidupan. Hal ini dijelaskan oleh Almond (2007: 35) bahwa pengalaman sosialisasi akan mempengaruhi tingkah laku politik di kemudian hari yang terjadi sebelumnya dalam kehidupan. Selanjutnya pengalaman tersebut bukan pengalaman yang bersifat politik tetapi memiliki berbagai konsekuensi politik laten yaitu yang tidak dimaksudkan melahirkan impak politik sedang impak tersebut tidak terorganisir adanya. Sosialisasi politik merupakan bagian yang penting dari suatu sistem politik karena dengan adanya sosialisasi politik maka seorang individu dapat mempelajari politik baik secara disadari ataupun tidak disadari oleh masing- masing individu tersebut.

2. Rekruitmen

Penyeleksian terhadap individu ataupun sekelompok orang dalam penempatan jabatan politik dalam sistem politik suatu negara. Fungsi rekrutmen tersebut dalam pengaplikasiannya diterapkan oleh partai politik disesuaikan dengan mekanisme masingmasing. Selain hal tersebut rekrutmen politik tidak hanya untuk mengisi jabatan politik semata tetapi kekuasaan yang lainnya. Dalam kaitannya terhadap partai politik, fungsi rekrutmen merupakan bagian yang sangat vital. Hal tersebut dikarenakan jika gagal melakukan fungsi rekrutmen politik, partai politik terancam keberlangsungan. Oleh sebab itu, partai politik memerlukan penyegaran keanggotaan untuk dapat bertahan dalam mempertahankan kekuasaan politiknya di mata masyarakat

3. Kaderisasi

Sumber daya manusia sebagai calon anggota dalam organisasi yang melakukan proses seleksi yang dilatih dan dipersiapkan untuk memiliki keterampilan dan disiplin ilmu. Proses seleksi dapat disebut juga kaderisasi. Fungsi dari kaderisasi adalah mempersiapkan calon-calon (embrio) yang siap melanjutkan tongkat estafet perjuangan sebuah organisasi.

4. Komunikasi

Sesuatu yang dilakukan oleh manusia atau individu dalam kehidupannya untuk memberikan pesan berupa informasi kepada individu lainnya. Sehingga terjalin hubungan diantara manusia atau individu tersebut

\section{Hasil Penelitian \\ Sosialisasi}

Menurut G.A. Almon (dalam Rahman 2007:29) sosialisasiadalah suatu proses yang dipengaruhi oleh pengalaman sebelumnya yang diperoleh individu dalam kehidupan. Pengalaman sosialisasi akan mempengaruhi tingkah laku politik di kemudian hari yang terjadi sebelumnya dalam kehidupan. Selanjutnya pengalaman tersebut bukan pengalaman yang bersifat politik tetapi memiliki berbagai konsekuensi politik laten yaitu yang tidak dimaksudkan melahirkan impak politik sedang impak tersebut tidak terorganisir adanya. 
Sosialisasi politik merupakan bagian yang penting dari suatu sistem politik karena dengan adanya sosialisasi politik maka seorang individu dapat mempelajari politik baik secara disadari ataupun tidak disadari oleh masing- masing individu tersebut.

Hasil wawancara dengan informan tentang keterwakilan perempuan dalam pemilihan legislatis di DPRD di Kota Sungai Penuh tahun 2019,yaitu:

"Keterwakilan perempuan dalam pemilihan legislatif sangat kurang. Sehingga masyarakat tidak begitu mengenal calon perempuan yang akan dipilih. Hal ini dikarenakan kurangnya sosialisasi terhadap masyarakat dan kurangnya existensi perempuan dalam pemilihan legislatif sehingga banyak masyarakat yang tidak mengenal tentang perempuan yang ikut dalam pemilihan legislatif 2019."

(Hasil wawancara dengan Bapak Lendra Wijaya pukul 10.30 Wib hari Rabu tanggal 15 Juli 2020)

"sosialisasi perempuan dalam pemilihan legislatif sangat kurang, banyak masyarakat yang tidak mengenal siapa perempuan yang dipilih untuk mewakili suara perempuan. Dan kepercayaan kepada perempuan di Dewan Perwakilan Rakyat Daerah (DPRD) belum sepenuhnya mendapatkan dukungan mutlak dari masyarakat karena sosialisasi kepada masyarakat sangat kurang."

(Hasil wawancara dengan Ibu Weti Retmalia pukul 13.15 Wib hari Rabu tanggal 15 Juli 2020)

"walaupun ada kuota suara untuk perempuan $30 \%$ tetapi ini tidak menjamin perempuan dapat terpilih dalam pemilihan legislatif 2019, kenyataannya tidak ada satupun yang mewakili suara perempuan di DPRD Kota Sungai Penuh. Hal ini sudah jelas karena kurangnya sosialisasi kepada masyarakat tentang keanggotaan mereka sehingga masyarakat tidak memilih calon perempuan dikarenakan kurang melakukan pendekatan dengan masyarakat.."

(Hasil wawancara denganIbu Mela Silvia pukul 11.10 Wib hari Senin tanggal 20 Juli 2020)

"sosialisasi keterwakilan perempuan dalam pemilihan legislatif tahun 2019 terhadap masyarakat sangat kurang, hal ini juga memberikan dampak masyarakat merasa tidak yakin akan pilihan mereka dengan memilih perempuan dalam pemilihan legislatif tahun 2019 di Kota Sungai Penuh dalam artian tidak ada yang populer."

(Hasil wawancara dengan Ibu Yola Anggaini pukul 10.15 Wib hari Kamis tanggal 23Juli 2020)

"sosialisasi keterwakilan perempuan sangat kurang sehingga tidak ada yang mewakili suara perempuan di Dewan Perwakilan Rakyat Daerah (DPRD) Kota Sungai penuh, untuk itu perlu bagi perempuan yang ikut dalam pemilihan legislatif untuk melakukan sosialisasi atau mendekatan-pendekatan dan berbaur dengan masyarakat, agar masyarakat tahu dan mendapatkan dukungan dari masyarakat karena suara perempuan dalam pemilu juga banyak."

(Hasil wawancara dengan Bapak Yoshadi pukul 11.10 Wib hari Rabu tanggal 29 Juli 2020)

Dari jawaban informan dapat diinterpretasikan bahwa sosialisasi tentang keterwakilan perempuan dalam pemilihan legislatif sangat kurang sehingga tidak mendapat dukungan mutlak dari masyarakat khususnya masyarakat perempuan untuk mewakili suara mereka di Dewan Perwakilan Rakyat Daerah (DPRD) Kota Sungai Penuh. Dalam hal ini Secara teori 
keterwakilan perempuan sebagai calon legislatif harus diiringi dengan proses sosialisasi, sedangkan dalam prakteknya sangat kurangnya sosialisasi sehingga masyarakat kurang mengenal calon-calon wakil perempuan di legislatif yang akan dipilih oleh masyarakat.

\section{Rekruitmen.}

Menurut G.A. Almon (dalam Rahman 2007:29) rekruitmen adalah penyeleksian terhadap individu ataupun sekelompok orang dalam penempatan jabatan politik dalam sistem politik suatu negara. Fungsi rekrutmen tersebut dalam pengaplikasiannya diterapkan oleh partai politik disesuaikan dengan mekanisme masing-masing. Selain hal tersebut rekrutmen politik tidak hanya untuk mengisi jabatan politik semata tetapi kekuasaan yang lainnya. Dalam kaitannya terhadap partai politik, fungsi rekrutmen merupakan bagian yang sangat vital. Hal tersebut dikarenakan jika gagal melakukan fungsi rekrutmen politik, partai politik terancam keberlangsungan. Oleh sebab itu, partai politik memerlukan penyegaran keanggotaan untuk dapat bertahan dalam mempertahankan kekuasaan politiknya di mata masyarakat

Hasil wawancara dengan informan tentang rekruitmen keterwakilan perempuan dalam pemilihan legistalif di DPRD Kota Sungai Penuh tahun 2019, Hasil wawancara dengan informan yaitu:

"Sistem rekruitmen perempuan di Dewan Perwakilan Rakyat Daerah (DPRD) sudah dilakukan sesuai peraturan yang ada. Dimana dengan adanya peraturan $30 \%$ pada setiap anggota partai politik dan hal ini sangat dimanfaatkan oleh perempuan di Kota Sungai Penuh hanya saja belum dapat mewakilkan suara perempuan di DPRD. Perekrutan perempuan dalam legislatif tidak ditunjang dengan dengan kualitas atau kepepopulerannya dalam masyarakat."

(Hasil wawancara dengan Bapak Lendra Wijaya pukul 10.32 Wib hari Rabu tanggal 15 Juli 2020)

"adanya peraturan keterwakilan dalam setiap partai pada pemilihan legislatif tahun 2019 untuk kuota perempuan sebanyak $30 \%$, dalam hal ini ternyata tidak menjadikan perempuan dapat terpilih di DPRD Kota Sungai Penuh. Bisa jadi dikarenakan rekruitmen perempuan yang dipilih tidak dikenal masyarakat atau yang tidak berkualitas baik secara akademik ataupun dalam bidang lain."

(Hasil wawancara dengan Ibu Weti Retmalia pukul 13.18 Wib hari Rabu tanggal 15 Juli 2020)

"keterwakilan perempuan dalam pemilihan legislatif belum dapat dikatakan maksimal. Tetapi adanya jumlah yang cukup besar dalam sistem rekruitmen memberikan peluang bagi perempuan untuk dapat mewakilkan perempuan dalam pemilihan legislatif, dan tentu saja perempuan juga termotivasi untuk ikut andil memanfaatkan peluang tersebut. Hanya belum ada yang mewakili suara permpuan di DPRD Kota Sungai Penuh."

(Hasil wawancara dengan Ibu Mela Silvia pukul 11.12 Wib hari Senin tanggal 20 Juli 2020)

"Keterwakilan perempuan di Dewan Perwakilan Rakyat Daerah (DPRD) Kota Sungai Penuh belum sepenuhnya dapat meningkatkan jumlah anggota terpilih di Dewan Perwakilan Rakyat Daerah (DPRD) Kota Sungai Penuh dikarenakan kurangnya pilihan masyarakat terhadap anggota perempuan pada pemilihan legislatif, sehingga keterwakilan perempuan di Dewan Perwakilan Rakyat Daerah (DPRD) Kota Sungai Penuh tidak dapat memenuhi suara perempuan yang jumlahnya cukup besar." 
(Hasil wawancara dengan Ibu Yola Anggaini pukul 10.20 Wib hari Kamis tanggal 23 Juli 2020)

"dengan adanya sistem rekruitmen 30\% untuk perempuan pada pemilihan legislatif tahun 2019 belum dapat mewakili suara perempuan di Dewan Perwakilan Rakyat Daerah (DPRD) Kota Sungai Penuh, kenyataan tidak dapat mendongkrak jumlah anggota perempuan terpilih untuk dapat mewakili kaumnya dikarenakan kurangnya dukungan untuk perempuan ."

(Hasil wawancara dengan Bapak Yoshadi pukul 11.14 Wib hari Rabu tanggal 29 Juli 2020)

Berdasarkan dari jawaban informan dapat diinterpretasikan, bahwa rekruitmen keterwakilan perempuan dalam pemilihan legislatif di Dewan Perwakilan Rakyat Daerah (DPRD) Kota Sungai Penuh dalam sistem rekruitmen tidak diiringi dengan kualitas, kapabilitas dan loyalitas terhadap partai yang dimasukinya, dimana dalam hal ini perempuan direkrut oleh partai tersebut hanya sekedar untuk memenuhi ketercukupan anggota $30 \%$ agar dapat masuk dalam pemilihan, sehingga tidak banyak dari masyarakat yang memilih kaum perempuan.Sedangkan secara teori rekruitmen calon legislatif harus dilakukan dengan pertimbangan kualitas dari calonnya karena keanggotaan seseorang yang tidak berkualitas akan mengancam keberadaan dari sebuah partai. Disini dilihat bahwa calon perempuan dalam legislatif dipilih hanya sekedar untuk memenuhi kuota saja tidak adanya sistem rekruitmen secara kontinyu terhadap perempuan yang menjadi wakil dalam legislatif.

\section{Kaderisasi}

Menurut G.A. Almon (dalam Rahman 2007:29) kaderisasi adalah sumber daya manusia sebagai calon anggota dalam organisasi yang melakukan proses seleksi yang dilatih dan dipersiapkan untuk memiliki keterampilan dan disiplin ilmu. Proses seleksi dapat disebut juga kaderisasi. Fungsi dari kaderisasi adalah mempersiapkan calon-calon (embrio) yang siap melanjutkan tongkat estafet perjuangan sebuah organisasi.

Hasil wawancara dengan informan tentang kaderisasi keterwakilan perempuan dalam pemilihan legislatis di DPRD Kota Sungai Penuh tahun 2019, yaitu:

"pengkaderan perempuan dalam pemilihan legislatif merupakan suatu hal yang sangat penting karena menyangkut keberlangsungan keberadaan dari suatu partai. Situasi di Kota Sungai Penuh pengkaderan Perempuan dalam pemilihan legislatif tidak ditunjang dengan kualitas calonnya, dan keterannya di masyarakat. Kehadiran perempuan pada pemilihan legislatif tahun 2019 tidak mampu mendongkrak keterwakilan perempuan di DPRD Kota Sungai Penuh. Bisa jadi karena masyarakat tidak memiliki kepercayaan terhadap perempuan yang akan mewakili suara mereka di DPRD."

(Hasil wawancara dengan Bapak Lendra Wijaya pukul 10.40 Wib hari Rabu tanggal 15 Juli 2020)

"keterwakilan perempuan dalam pemilihan legislatif tidak didukung oleh pengkaderan yang serius bahkan terdaftarnya pun sudah mendekati batas pedaftaran anggota legislatif, terkesan habnya untk memenuhi jumlah perempuan dalam suatu partai."

(Hasil wawancara dengan Ibu Weti Retmalia pukul 13.20 Wib hari Rabu tanggal 15 Juli 2020)

"walaupun ada kuota suara untuk perempuan $30 \%$ tetapi ini tidak menjamin perempuan dapat terpilih dalam pemilihan legislatif 2019, hal ini dapat dilihat karena kehadiran 
perempuan dalam partai hanya sekedar untuk memenuhi kuota tidak ada ambisi untuk dipilih. Dan memang masyarakat sudah cerdas tidak memilih anggota yang tidak mereka kenal, dapat dikatakan kaderisasi untuk perempuan di Kota Sungai Penuh dalam pemilihan legislatif sangat kurang, dalam artian tidak melihat kualitas dan kepepopulerannya di masyarakat."

(Hasil wawancara dengan Ibu Mela Silvia pukul 11.14 Wib hari Senin tanggal 20 Juli 2020)

"kaderisasi keterwakilan perempuan dalam pemilihan legidrslatif tahun 2019 terhadap masyarakat sangat kurang, seharusnya jauh-jauh waktu pendaftaran angggota sudah dilakukan pengkaderan sehingga persiapan untuk dipilih dalam pemilihan legislatif betul-betul keberadaannya di akui oleh amsyarakat, sehingga masyarakat merasa tidak yakin akan pilihan mereka dengan memilih perempuan dalam pemilihan legislatif tahun 2019 di Kota Sungai Penuh dalam artian tidak ada yang cocok dihati masyarakat untuk mendukung kaum mereka."

(Hasil wawancara dengan Ibu Yola Anggaini pukul 10.18 Wib hari Kamis tanggal 23 Juli 2020)

"kadersiasi keterwakilan perempuan dalam pemilihan legislatif tahun 2019 belum maksimal terpilihnya perempuan dalam partai rata-rata urutan nomor anggota pada urutan-urutan terakhir dan terkesan hanya untuk melengkapi kuota karena urutan nomor keanggotaan partai sangat menentukan terpilihnya menjadi anggota DPRD di Kota Sungai Penuh. Disini dapat dilihat bahwa keanggotaan tersebut dipilih secara dadakan tanpa adanya kaderisasi."

(Hasil wawancara dengan Bapak Yoshadi pukul 11.13 Wib hari Rabu tanggal 29 Juli 2020)

Dari jawaban informan dapat diinterpretasikan bahwa kaderisasi keterwakilan perempuan dalam pemilihan legislatif sangat kurang sehingga tidak mendapat dukungan mutlak dari masyarakat khususnya masyarakat perempuan untuk mewakili suara mereka di Dewan Perwakilan Rakyat Daerah (DPRD) Kota Sungai Penuh. Sedangkan Secara teori pengkaderan anggota sangat penting karena merupakan embrio dari keberlangsungan suatu keanggotaan seseorang dalam legislatif, sedangkan kenyataan dilapangan pengkaderan anggota masih kurang serius dalam artian tidak dicari calon-calon dari jauh-jauh hari, bahkan ada yang didaftarkan beberapa hari sebelum pendaftaran parpol secara resmi.

\section{Komunikasi}

Menurut G.A. Almon (dalam Rahman 2007:29) komunikasi adalah sesuatu yang dilakukan oleh manusia atau individu dalam kehidupannya untuk memberikan pesan berupa informasi kepada individu lainnya. Sehingga terjalin hubungan diantara manusia atau individu tersebut.

Hasil wawancara dengan informan tentang komunikasi keterwakilan perempuan dalam pemilihan legislatis di DPRD Kota Sungai Penuh tahun 2019, yaitu:

"komunikasi anggota perempuan dengan masyarakat dalam pemilihan legislatif tahun 2019 di Kota Sungai Penuh sangat kurang, sehingga tidak adanya keterwakilan perempuan di DPRD Kota Sungai Penuh. Hal ini juga berkaitan dengan kenal tidaknya masyarakat dengan anggota legislatif perempuan yang akan dipilihnya, ibarat kata tak tahu maka tak kenal, tak kenal maka tak sayang. kebanyakan anggota legislatif perempuan tidak dikenal dengan baik dan mendalam oleh masyarakat." 
(Hasil wawancara dengan Bapak Lendra Wijaya pukul 10.30 Wib hari Rabu tanggal 15 Juli 2020)

"komunikasi sosialisasi perempuan dalam pemilihan legislatif sangat kurang, masyarakat banyak yang tidak tahu profil tentang perempuan-perempuan yang ada nama dan fotonya dalam daftar pemilihan legislatif tahun 2019 di Kota Sungai Penuh." (Hasil wawancara dengan Ibu Weti Retmalia pukul 13.15 Wib hari Rabu tanggal 15 Juli 2020)

"kurangnya minat masyarakat memilih anggota legislatif tahun 2019 dikarenakan kurang komunkasi calon dengan masyarakat sehingga masyarakat tidak mengenal dengan baik sehingga berdampak kurangnya minat masyarakat memilih anggota legislatif yang perempuan."

(Hasil wawancara dengan Ibu Mela Silvia pukul 11.10 Wib hari Senin tanggal 20 Juli 2020)

"dalam berkomunikasi kebanyakan perempuan yang mencalonkan diri pada pemilihan legislatif tahun 2019 kurang pandai mengambil hati masyarakat, kurang berbaur dengan masyarakat sehingga kehadiran perempuan pada daftar nama-nama anggota partai yang ikut pada pemilihan legislatif 2019 hanya sebagai meramaikan saja."

(Hasil wawancara dengan Ibu Yola Anggaini pukul 10.15 Wib hari Kamis tanggal 23 Juli 2020)

"komunikasi perempuanyang menjadi anggota dalam partai sangat kurang sehingga masyarakat tidak tahu sama sekali keberadaan perempuan-perempuan yang dipilih paling hanya keluarga dekat dan masyarakat sekitaran tempat tinggalnya, karena tidak adanya menjalin hubungan baik dengan masyarakat pemilihnya."

(Hasil wawancara dengan Bapak Yoshadi pukul 11.10 Wib hari Rabu tanggal 29 Juli 2020)

Dari jawaban informan dapat diinterpretasikan bahwa kurangnya komunikasi perempuan yang mewakili partainya pada pemilihan kegislatif tahun 2019terhadap masyarakat pemilihnya dan kurang menjalin hubungan baik dengan masyarakat sehingga masyarakat tidak berkeinginan untuk memilih karena kurang dikenali.

Secara teori sangat penting melakukan komunikasi untuk menarik masyarakat agar mengenal calon legislatif perempuan yang akan mewakili suara mereka di DPRD, sedangkan prakteknya keterwakilan perempuan dalam legislatif 2019 tidak ada yang mewakili perempuan dikarenakan kurangnya calon legislatif perempuan melakukan komunikasi dengan masyarakat, kurang melakukan pendekatan sehingga masyarakat kurang kenal dan tahu siapa calon perempuan yang dipilihnya.

\section{Faktor-faktor apa saja yang mempengaruhi keterwakilan perempuan dalam Pemilihan Legislatif (Studi Kasus Di DPRD Kota Sungai Penuh tahun 2019).}

Hasil wawancara dengan informan tentang faktor-faktor yang mempengaruhi keterwakilan perempuan dalam pemilihan legislatis di DPRD Kota Sungai Penuh tahun 2019, yaitu:

"faktor-faktor yang mempengaruhi keterwakilan perempuan pada pemilihan legislatif dikarenakan hanya untuk memenuhi kuota perempuan $30 \%$ pada setiap partai agar dapat lolos dalam pemilu, tetapi kurangnya pembinaan terhadap kader-kader dengan 
baik dan secara kontinyu sehingga keterwakilan perempuan belum dapat membuat masyarakat yakin untuk mendukung ke DPRD ."

(Hasil wawancara dengan Bapak Lendra Wijaya pukul 10.30 Wib hari Rabu tanggal 15 Juli 2020)

"keterwakilan perempuan dalam legislatif sebagian didasarkan pada keinginan untuk coba-coba berkiprah dikancah politik, mana tau bisa dapat suara banyak dan menjadi anggota DPRD."

(Hasil wawancara dengan Ibu Weti Retmalia pukul 13.15 Wib hari Rabu tanggal 15 Juli 2020)

"Untuk mewakili suara perempuan di DPRD Kota Sungai Penuh agar aspirasi perempuan dapat terwakilkan, walaupun kenyataan tidak ada yang mewakili suara perempuan."

(Hasil wawancara dengan Ibu Mela Silvia pukul 11.10 Wib hari Senin tanggal 20 Juli 2020)

"Untuk mengembangkan bakat dan keinginan di dunia politik agar kaum perempuan juga dapat berkiprah dikancah politik tidak hanya kaum laki-laki saja."

(Hasil wawancara dengan Ibu Yola Anggaini pukul 10.15 Wib hari Kamis tanggal 23 Juli 2020)

"kehadiran perempuan dalam pemilihan legislatif tahun 2019 tidak diiringi dengan dukungan dari masyarakat sepertinya masyarakat belum begitu percaya dengan anggota partai yang perempuan, secara sederhana dapat diartikan kurang keseriusan kaum perempuan dalam memperoleh suara seperti kurang dukungan moril dan materil."

(Hasil wawancara dengan Bapak Yoshadi pukul 11.10 Wib hari Rabu tanggal 29 Juli 2020)

Dari jawaban informan dapat diinterpretasikan bahwa faktor-faktor yang mempengaruhi keterwakilan perempuan dalam pemilihan legislatis di DPRD Kota Sungai Penuh tahun 2019 adalah :

1. Hanya sekedar untuk memenuhi kuota keterwakilan perempuan dilegislatif 2019. kurangnya komunikasi perempuan yang mewakili partainya pada pemilihan kegislatif tahun 2019 terhadap masyarakat pemilihnya dan kurang menjalin hubungan baik dengan masyarakat sehingga masyarakat tidak berkeinginan untuk memilih karena kurang dikenali.

2. Keterwakilan perempuan dalam legislatif sebagian didasarkan pada keinginan untuk cobacoba berkiprah dikancah politik

3. Untuk mewakili suara perempuan di DPRD Kota Sungai Penuh agar aspirasi perempuan dapat terwakilkan

4. Untuk mengembangkan bakat dan keinginan di dunia politik agar kaum perempuan juga dapat berkiprah dikancah politik

5. kurang keseriusan kaum perempuan dalam memperoleh suara seperti kurang dukungan moril dan materil

Secara teori dapat dilihat bahwa faktor-faktor yang mempengaruhi keterwakilan perempuan tidak diiringi dengan seriusan dalam pengkaderan anggotanya, tidak membuka komunikasi yang baik dengan masyarakat pemilih, kurangnya sosialisasi sehingga pemilih kurang dikenal dikalangan masyarakat. 


\section{PENUTUP}

\section{Kesimpulan}

Dari hasil penelitian diatas dapat disimpulkan bahwa keterwakilan perempuan dalam pemilu legislatif tahun 2019 di DPRD Kota Sungai Penuh belum dapat mewakili suara perempuan, dikarenakan kurangnya sosialisasi, rekruitmen, kaderisasi, dan komunikasi. Dari keempat indikator yang diujikan tidak ada satu indikator penelitian yang dilaksanakan dengan maksimal terhadap keterwakilan perempuan dalam legislatif tahun 2019 di DPRD Kota Sungai Penuh, yaitu:

1. Sosialisasi tentang keterwakilan perempuan dalam pemilihan legislatif sangat kurang sehingga tidak mendapat dukungan mutlak dari masyarakat khususnya masyarakat perempuan untuk mewakili suara mereka di Dewan Perwakilan Rakyat Daerah (DPRD) Kota Sungai Penuh

2. Rekruitmen keterwakilan perempuan dalam pemilihan legislatif di Dewan Perwakilan Rakyat Daerah (DPRD) Kota Sungai Penuh dalam sistem rekruitmen tidak diiringi dengan kualitas, kapabilitas dan loyalitas terhadap partai yang dimasukinya, dimana dalam hal ini perempuan direkrut oleh partai tersebut hanya sekedar untuk memenuhi ketercukupan anggota $30 \%$ agar dapat masuk dalam pemilihan, sehingga tidak banyak dari masyarakat yang memilih kaum perempuan.

3. Kaderisasi keterwakilan perempuan dalam pemilihan legislatif sangat kurang sehingga tidak mendapat dukungan mutlak dari masyarakat khususnya masyarakat perempuan untuk mewakili suara mereka di Dewan Perwakilan Rakyat Daerah (DPRD) Kota Sungai Penuh.

4. Komunikasi perempuan yang mewakili partainya pada pemilihan kegislatif tahun 2019 terhadap masyarakat pemilihnya dan kurang menjalin hubungan baik dengan masyarakat sehingga masyarakat tidak berkeinginan untuk memilih karena kurang dikenali.

5. Faktor-faktor penyebab kurangnya keterwakilan perempuan pada pemilu legislatif tahun 2019 di Kota Sungai penuh adalah :

a. Kurangnya komunikasi perempuan yang mewakili partainya pada pemilihan kegislatif tahun 2019 terhadap masyarakat pemilihnya dan kurang menjalin hubungan baik dengan masyarakat.

b. Keterwakilan perempuan dalam legislatif sebagian didasarkan pada keinginan untuk coba-coba berkiprah dikancah politik

c. Untuk mengembangkan bakat dan keinginan di dunia politik agar kaum perempuan juga dapat berkiprah dikancah politik

\section{Saran}

Bagi perempuan-perempuan yang ingin menjadi wakil rakyat di DPRD Kota Sungai Penuh hendaknya mempersiapkan diri dengan meningkatkan kualitas diri dalam :

1. Agar dapat meningkatkan sosialisasi dengan masyarakat supayaa keterwakilannya dalam legislatif dapat didukung oleh masayarakat

2. Agar keterwakilan perempuan dalam legialatif dapat dilakukan proses rekruitmen secara maksimal.

3. Agar keterwakilan perempuan dapat melakukan pengkaderan secara kontinyu sehingga keterwakilan dalam legislatif mendapat dukungan dari masyartakat.

4. Agar keterwakilan perempuan dapat menjalin komunikasi yang baik dengan masyarakat dan mendapat dukungan dari masyarakat

5. Diharapklan Keterwakilan perempuan dalam legislatif tidak hanya sekedar untuk memenuhi kuota, dapat lebih serius dan meningkatkan kualitas diri agar masyarakat yakin dengan pilihan merfeka terhadaap perempuan pada pemilihan legislatif yang akan datang. 


\section{DAFTAR PUSTAKA}

Alexander, Abe. (2002). Perencanaan Daerah Partisipatif. Yogyakarta: Pustaka Jogya Mandiri.

Bolgherini. (2010). "Participation" dalam Mauro Calise and Theodore J.

Lowi, Hyperpolitics: An Interactive Dictionary of Political Science Concept . The University of Chicago. Chicago.

Pebi Julianto. 2014. Evaluasi Pelaksanaan Program Satu milyar Satu kecamatan (Samisake) di kecamatan Depati Tujuh Kabupaten Kerinci Provinsi jambi tahun 2014. OSF Preprints. Jakarta.

Bugin, B (2003). Analisis Data Penelitian Kualitatif, Rajawali Pers : Jakarta.

Cohen dan Uphoff. ( 2011). Rural Development Participation. New York: Ithaca.

Cornelis lay. (1997). Democratic Transition in Local Indonesia: An Overview of Ten Years Democracy.

Pebi Julianto. 2020. Pengaruh Disiplin Kerja Terhadap Prestasi Kerja Pegawai pada Puskesmas di kecamatan Depati VII Kabupaten Kerinci. E Jurnal Administrasi Nusantara. Sungai Penuh.

Danim, Sudarwan. (2002). Menjadi Peneliti Kualitatif, Pustaka Setia. Bandung

Fasli Jalal dan Dedi Supriadi (2001). Reformasi Pendidikan Dalam Konteks Otonomi Daerah, Yogyakarta: Adicita Karya Nusa.

F. Winarni. (2013). Cakrawala Pendidikan No.1Tahun XVI, Februari Jakarta

H.A.R. Tilaar. (2009). Pengembangan Sumber Daya Manusia dalam Era Globalisasi. Gramedia. Jakarta

Pebi Julianto. 2018. Pengaruh Sistem Kearsipan Terhadap Efisiensi Kerja Pada koantor Camat Air Hangat Kabupaten Kerinci. E Jurnal Administrasi Nusantara. Sungai Penuh.

I Nyoman Sumardi. (2010). Perencanaan Pembangunan Daerah Otonom dan Perbedayaan Masyarakat. Citra Utama. Jakarta

Jhon M.Echol dan Hasan Sadily. 2000. Kamus Inggris - Indonesia. PT Gramedia Pustaka Utama. Jakarta.

Juliantara. (2002). Pembaruan Desa: Bertumpu pada Apa yang Terbawa. Lapera Pustaka Utama. Yogyakarta.

Pebi Julianto. 2018. Pengaruh Pengetahuan dan Keterampilan Terhadap Prestasi Kerja Pegawai Pada Mtsn Model Sungai Penuh. E Jurnal Administrasi Nusantara. Sungai Penuh.

Lexy J. Moleong. (2009). Metode Penelitian Kualitatif. Erlangga. Jakarta

Miftaf Thoha. (2003). Perilaku Organisasi Konsep Dasar dan Aplikasinya. Rajawali Grafindo Persada. Jakarta

Miles dan Emzir, (2010). MetodologiPenelitian Kualitatif Analisis Data, Jakarta: Rajawali Pers.

Pebi Julianto. 2020. Implementasi Program Bantuan Pangan non Tunai (BPNT) di Kecamatan Sitinjau Laut Kabupaten Kerinci. E Jurnal Qawwam. Kerinci.

Miriam Budiardjo (2008) Dasar-dasar Ilmu Politik, Gramedia.

Mohtar Mas'oed. (2000). Perbandingan Ilmu Politik, Gadjah Mada University Press, Yogyakarta.

Morrison. (2005). Segi Manusia Dalam Manajemen. Aksara Baru. Jakarta

Nazarudin Syamsudin. (2007). Integrasi Poilitik di Indonesia. Gramedia. Jakarta 
Pebi Julianto. 2021. Pengaruh hard Skill dan Pelatihan Terhadap Kinerja Aparatur Sipil Negara Pada Kantor Camat Airn Hangat Kabupaten Kerinci. E Jurnal Administrasi Mahasiswa. Sungai Penuh.

Prihatmoko, Joko J. (2003). Pemilu 2004 dan Konsolidasi Demokrasi. Semarang: LP2I Press.

Ramlan Surbakti. (2002). Memahami Ilmu Politik, Jakarta: Gramedia

Samuel P Huntington \& Nelson, Joan. (2000). Partisipasi Politik di Negara Berkembang. Rineka Cipta. Jakarta:

Sugiono. (2007).Memahami Penelitian Kualitatif. Bandung: CV. Alfabeta.

Suqiyah. (2001). Otonomi Perempuan, Malang: Bayumedia Publishing.

Pebi Julianto. 2020. Partisipasi Masyarakat Dalam Program Bantuan Stimulan Perumahan Swadaya (BSPS) di Desa Koto Baru Kecamatan Koto baru (2020). E Jurnal Qawwam. Kerinci.

Sunyoto Usman. (2018). Gerakan melawan Elite. PT Cipta Marga. Jakarta Thomas. M. Magstad. (2014). Understanding Politics: Ideas, Institutions, and Issues. Cengage Learning 